\title{
Response to: "Rescuing the NIH before it is too late"
}

\begin{abstract}
We, the directors of the $27 \mathrm{NIH}$ institutes and centers, wanted to respond to the points made by Andrew Marks in his recent editorial. While we appreciate that the scientific community has concerns, the current initiatives and directions of the NIH have been developed through planning processes that reflect openness and continued constituency input, all aimed at assessing scientific opportunities and addressing public health needs.
\end{abstract}

Your editorial raises many important issues that affect NIH-funded researchers (1).

However, the personal attack on Dr. Elias Zerhouni is unfair, inappropriate, and obscures discussion of the real issues of concern to the entire NIH research community. We fully appreciate the anxiety and concern that individual investigators feel during periods of severe fiscal constraints. While these concerns are understandable, they must be balanced by the need to move the research enterprise forward strategically, coordinating efforts across the $27 \mathrm{NIH}$ institutes and centers to overcome the major shared impediments to biomedical progress.

In the face of progressive budget tightening and pressure to be held accountable to the American public and members of Congress, Dr. Zerhouni has pursued a forwardlooking approach to sustain our commitment to basic research while developing innovative ways to translate basic discoveries into clinical practice.

We who work closely with Dr. Zerhouni know him to be a creative scientist as well

Duane F. Alexander, MD

Director, National Institute of Child Health and Human Development

Barbara M. Alving, MD

Acting Director, National Center for

Research Resources

James F. Battey Jr., MD, PhD

Director, National Institute on Deafness

and Other Communication Disorders

Jeremy M. Berg, PhD

Director, National Institute of General

Medical Sciences

Francis S. Collins, MD, PhD

Director, National Human Genome Research Institute

Anthony S. Fauci, MD

Director, National Institute of Allergy and Infectious Diseases

John I. Gallin, MD

Director,

NIH Clinical Center as a skillful communicator of science to the Congress and the public. Each of us knows his commitment to innovation and to recruiting and retaining the best minds in biomedical research. Dr. Zerhouni has fought relentlessly to increase NIH funding despite difficult budgetary circumstances for the country as a whole and has articulated the public health mandate for science and the unprecedented opportunities for progress. Witness his most recent testimony to Congress (http://www. nih.gov/about/director/budgetrequest/ fy2007directorsbudgetrequest.htm). To blame him for the current budget reflects a poor understanding of his efforts and of the appropriation process.

With regard to your criticism of the Roadmap, there are some facts worth noting. The Roadmap was developed with broad input from the research community and the public. The Roadmap budget represents $1.2 \%$ of the total FY06 NIH budget and incorporates built-in constraints on growth. It provides a mechanism by which

Patricia A. Grady, PhD, RN, FAAN

Director, National Institute of Nursing

Research

Richard J. Hodes, MD

Director,

National Institute on Aging

Sharon H. Hrynkow, PhD

Acting Director, John E. Fogarty

International Center

Thomas R. Insel, MD

of Mental Health

Jack F. Jones, PhD

Acting Director, Center for Information Technology

Stephen I. Katz, MD, PhD

Director, National Institute of Arthritis and

Musculoskeletal and Skin Diseases

Story C. Landis, PhD

Director, National Institute of Neurological Disorders and Stroke
Director, National Institute all NIH institutes and scientists can participate in initiatives that would be difficult to support within single institutes. The Roadmap increases the NIH commitment to innovation, to interdisciplinary research, and to translational medicine and has garnered considerable enthusiasm in Congress from both the Appropriations and Authorizing committees. Finally, we strongly disagree with the premise that clinical trials should only be conducted by pharmaceutical companies. The NIH is funded by taxpayers to whom we have the responsibility and privilege of providing new information that is relevant, unbiased, and fully accessible, including the fruits of clinical trials that industry will not support.

We are acutely aware that these are challenging times for the research community. Despite what remains a robust NIH budget, meritorious opportunities remain unfunded. We are pained to witness the departure of promising, young investigators from science, and this is why the NIH has launched new investigator awards programs. As investigators ourselves, many as members of the ASCI, we share the currents of frustration and anxiety within the research community, and we welcome continued input from the scientific community on such matters of understandable concern.

Ting-Kai Li, MD

Director, National Institute on Alcohol

Abuse and Alcoholism

Donald A. Lindberg, MD

Director,

National Library of Medicine

Elizabeth G. Nabel, MD

Director, National Heart, Lung, and Blood Institute

John E. Niederhuber, MD

Deputy Director,

National Cancer Institute

Roderic I. Pettigrew, MD, PhD

Director, National Institute of Biomedical

Imaging and Bioengineering

Griffin P. Rodgers, MD, MACP

Acting Director, National Institute of Diabetes and Digestive and Kidney Diseases

John Ruffin, PhD

Director, National Center on Minority

Health and Health Disparities 
Antonio Scarpa, MD, PhD

Director

Center for Scientific Review

David A. Schwartz, MD

Director, National Institute of

Environmental Health Sciences

Paul A. Sieving, MD, PhD

Director,

National Eye Institute
Stephen E. Straus, MD

Director, National Center for

Complementary and Alternative Medicine

Lawrence A. Tabak, DDS, PhD

Director, National Institute

of Dental and Craniofacial Research

Nora D. Volkow, MD

Director, National Institute

on Drug Abuse
Address correspondence to: Janet S. Austin, austinj@mail.nih.gov.

J. Clin. Invest. 116:1462-1463 (2006). doi:10.1172/JCI28894.

1. Marks, A.R. 2006. Rescuing the NIH before it is too late. J. Clin. Invest. 116:844. doi:10.1172/ JCI28364.

\section{Planning science (a generation after Lewis Thomas)}

\begin{abstract}
Andrew Marks' recent editorial eloquently reiterated a concern that many of us have voiced before, that the current policies and practices of the NIH are not serving the public well.
\end{abstract}

In no aspect of public life is the subversion of original science to bureaucratic need more evident than in the recent effort of the NIH, including its present director and the cadre he has enlisted, to centralize the direction of biomedical research. By means of extravagant Roadmaps or Translational Research Centers, they are crippling what has been the most successful research mechanism devised in the United States: the R01.

But in keeping with the custom of their band, the central planners are marching to music written a generation ago. In 1974, Lewis Thomas already complained that "It is administratively fashionable in Washington to attribute the delay of applied science in medicine to a lack of planning ... Do we need a new system of research management, with all the targets in clear display, arranged to be aimed at?” (1).

Thomas also presented an alternative to the best-laid plans of NIH mice and men, to the notion that protocols from above can direct our science. Lewis Thomas again said, "What [research] needs is for the air to be made right. If you want a bee to make honey, you do not issue protocols on solar navigation or carbohydrate chemistry, you put him together with other bees ... and you do what you can to arrange the general environment around the hive. If the air is right, the science will come in its own season, like pure honey" (1).
The R01s made the air right, and working scientists today are far more likely to support the editor of the JCI in his effort to protect them (2) than they are ready to support the shock and awe of NIH planning.

\section{Gerald Weissmann, MD \\ Editor in Chief, \\ The FASEB Journal}

Address correspondence to: Gerald Weissmann,weissg01@endeavor.med.nyu.edu.

J. Clin. Invest. 116:1463 (2006). doi:10.1172/ JCI28895.

1. Thomas, L. 1974. The lives of a cell: notes of a biology watcher. Viking Press. New York, New York, USA. 153 pp.

2. Marks, A.R. 2006. Rescuing the NIH before it is too late. J. Clin. Invest. 116:844. doi:10.1172/ JCI28364.

\section{Response to: "Rescuing the $\mathrm{NIH}$ before it is too late" from the Deputy Director for Extramural Research}

For a number of reasons, the NIH and the biomedical research community are facing a period of fiscal constraint after pronounced growth. In these difficult times, it is important that we all speak from the facts and work together to do a better job of explaining the importance of the nation's investment in biomedical research.

I would like to take this opportunity to respond to the recent editorial (1) raising concerns about the current and future the NIH budget picture and how the NIH manages during a time of fiscal constraint. I agree that there are reasons for serious concern in the scientific com- munity. Adjusting to the new budget realities is difficult, especially after a pronounced period of growth. For this reason, it is important that NIH leadership, grantees, and grantee institutions engage in an open dialogue about managing during tough times. We must, however, speak from the facts - not misinformation, rumor, or speculation.

Clearly, there is great concern about the dropping success rates. In this regard, I would first point out that the drop in success rates is not due to a major shift in the balance of our investments. We continue to support basic research at relatively the same level as in the past - the percentage of basic and applied science funding at NIH was at $55 \%$ and $41 \%$ of the NIH budget, respectively, in 2005, as compared to $54 \%$ and $41 \%$ in 1998 . The drop 